\title{
Tracheobronchopathia osteochondroplastica: a mouthful or an airway full?
}

\section{Anneliese Simons, ${ }^{1}$ James Finnerty, ${ }^{1}$ Natalie Meara ${ }_{1}{ }^{2}$ Ian Benton ${ }^{1}$}

${ }^{1}$ Department of Respiratory Medicine, Countess of Chester, Chester, UK

${ }^{2}$ Department of Histopathology, Countess of Chester, Chester, UK

\section{Correspondence to}

Dr Anneliese Simons, anneliesesimons@yahoo.co.uks

Accepted 13 November 2014

\section{DESCRIPTION}

An 80-year-old man was referred to the lung cancer clinic with a CT scan showing irregularity in the trachea and larger airways (figure 1). He had a history of prostate cancer, rheumatoid arthritis, colonic polyps and diverticulosis. He had no cough, haemoptysis or difficulty in breathing.

A bronchoscopy was arranged, which demonstrated diffuse mucosal irregularity throughout the trachea and main bronchi with sparing of the posterior membranous wall (figure 2). Histology confirmed connective tissue with foci of cartilage and

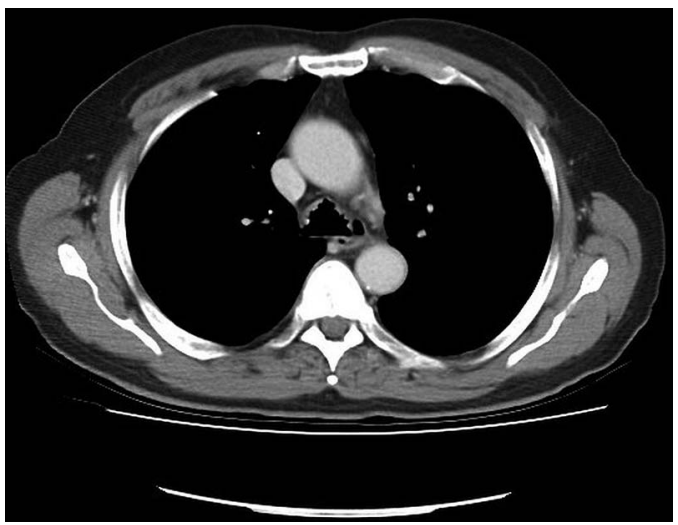

Figure $1 \mathrm{CT}$ of the chest demonstrating mucosal irregularity in the trachea.

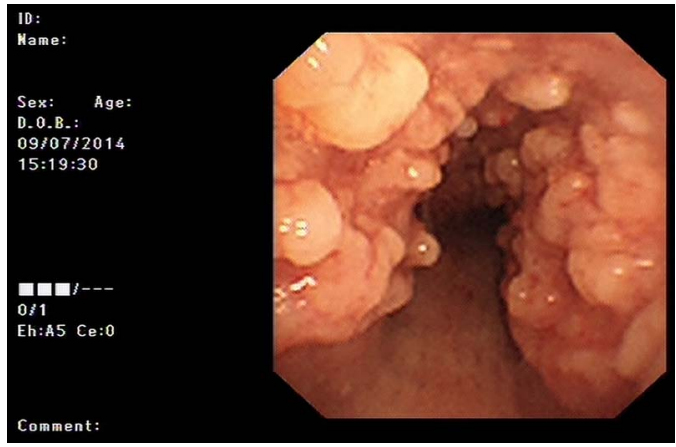

Figure 2 Mucosal irregularity in the trachea with sparing of posterior membranous wall.

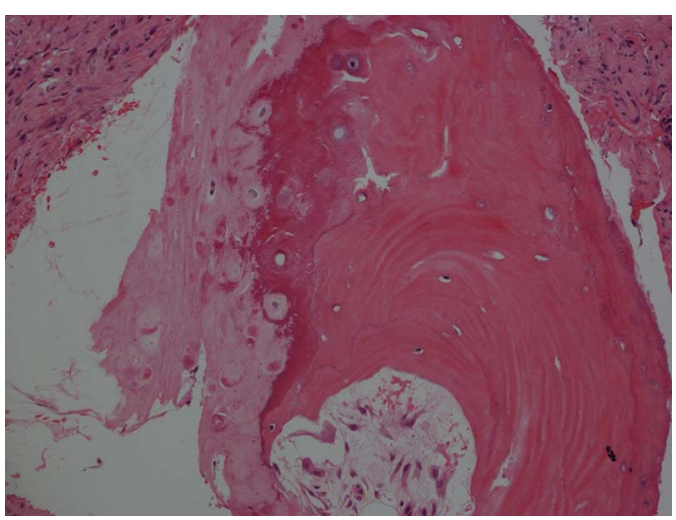

Figure 3 Histology slide showing normal bronchial mucosa with cartilaginous and osseous metaplasia.

bone consistent with a diagnosis of tracheobronchopathia osteochondroplastica (figure 3).

\section{Learning points}

- This is a rare benign condition characterised by abnormal growth of cartilage. In many cases it is asymptomatic but may cause cough, dyspnoea and hoarse voice. ${ }^{1}$ In severe cases it can result in airway obstruction amenable to linear tracheoplasty. ${ }^{2}$
To cite: Simons $A$ Finnerty J, Meara N, et al. BMJ Case Rep Published online: [please include Day Month Year] doi:10.1136/ bcr-2014-208013
Contributors AS wrote the script and collated the images. JF proofread the script. NM provided the histology slide. IB provided the bronchoscopy photo.

Competing interests None.

Patient consent Obtained.

Provenance and peer review Not commissioned; externally peer reviewed.

\section{REFERENCES}

1 Zack JR, Rozenshtein A. Tracheobronchopathia osteochondroplastica: report of three cases. J Comput Assist Tomogr 2002;26:33-6.

2 Grillo HC, Wright CD. Airway obstruction owing to tracheopathia osteoplastica: treatment by linear tracheoplasty. Ann Thorac Surg 2005:79:1676-81. 
Copyright 2014 BMJ Publishing Group. All rights reserved. For permission to reuse any of this content visit http://group.bmj.com/group/rights-licensing/permissions.

BMJ Case Report Fellows may re-use this article for personal use and teaching without any further permission.

Become a Fellow of BMJ Case Reports today and you can:

- Submit as many cases as you like

- Enjoy fast sympathetic peer review and rapid publication of accepted articles

- Access all the published articles

- Re-use any of the published material for personal use and teaching without further permission

For information on Institutional Fellowships contact consortiasales@bmjgroup.com

Visit casereports.bmj.com for more articles like this and to become a Fellow 